\title{
Study of Fluoride Concentration of Ground Water Samples In Different Tehsils of Osmanabad District
}

\author{
D. U. PATIL, P. B. GOREPATIL, Y. D. MANE and V. S. INGLE* \\ Post Graduate and Research Center, Department of Chemistry, \\ S.C.S. College, Omerga-413606, Osmanabad (M.S.), India.
}

http://dx.doi.org/10.12944/CWE.9.3.43

(Received: August 27, 2014; Accepted: September 15, 2014)

\begin{abstract}
This paper deals with the determination of fluoride concentration of ground water samples from Omerga, Lohara, Tuljapur and Osmanabad Tehsils. It was carried out using ion selective electrode and outcomes of the results were discussed in the light of pollution status of the study area. Monthly Changes in concentration of fluoride were analyzed for a periods of one year from June 2010 to May 2011. All Parameters were within the permissible limits. Data analysis revealed that a considerable variation of the water quality due to the different land use characteristics.
\end{abstract}

Key words: Fluoride ion concentration, Ground water samples, Fluoride-Ion- Electrode (IORN), ORION 407 A lon Meter .

\section{INTRODUCTION}

Osmanabad district is known as a religions district in Marathwada region of Maharashtra. A famous temple of "GoddessTuljabhavani" is situated in Tuljapur city, $18 \mathrm{~km}$ away from Osmanabad. A famous Naldurg fort is situated at Naldurg, $55 \mathrm{~km}$ away from Osmanabad.

Water is the basis of existence of all life in the Universe. Safe drinking water is the prime need of even life to sustain. The people of Osmanabad district usually use water from dam, dug well and bore well. Water from these sources is not always safe to drink because of rapid industrial growth, sewage, use of fertilizers, herbicides, insecticides in field; over irrigation of field etc. various chemicals from different sources are responsible for aquatic pollution $^{1-9}$. Among these pollutants high fluoride concentration has been reported from different parts of India. The fluoride concentration is increasing beyond the safe limit of $1.5 \mathrm{ppm}$ or $1.5 \mathrm{mg} /$ liter. A fluoride ion $^{10}$ concentration beyond tolerable limit is responsible for fluorosis, a disease related with dental and skeletal tissue.

Excessive fluoride ${ }^{11}$ ion concentration in ground water is a common problem in different parts of India. In Maharashtra state Osmanabad district where patients of fluorosis is increasing at a considerable rate. By taking this fact into account, the present work attempts to evaluate the ground water quality in Osmanabad district.

\section{MATERIALS AND METHOD}

Twenty ground water ${ }^{12-13}$ samples were randomly picked in Osmanabad district of Maharashtra state. The locations of the sampling points were spread within the length and breadth of the community. All samples were collected same day and kept in two liters rubber bottles, which was previously washed with $10 \% \mathrm{HNO}_{3}$ and $1: 1$ $\mathrm{HCl}$ for $48 \mathrm{~h}$. The rubber bottles were labeled and immediately few drops of $\mathrm{HNO}_{3}$ were added in order to prevent loss of metals, bacterial and fungal growth. 
Temperature, turbidity, and $\mathrm{pH}$ of water samples were also measured at the time of collection.

In the water study ground water samples (bore well) were collected from Omerga, Lohara, Tuljapur and Osmanabad tehsils with necessary precautions and preserved as per the recommended procedures ${ }^{14}$.All the chemicals used were of $A R$ grade, glass ware used were of $A$ Grade. Double distilled water was used throughout the work to prepare standard solutions ${ }^{15}$.

Fluoride concentration in aqueous samples was determined with Fluoride-Ion- Electrode (IORN) and ORION 407 Alon Meter. A $25 \mathrm{ml}$ of aliquot was taken in polythene beaker and $25 \mathrm{ml}$ of TISABIII (Total Ionic Strength Adjuster buffer, ORION application solutions) was added. Ion meter was standardized against solution of known fluoride concentration in the standard samples and read directly on the meter scale. The scale was calibrated in ppm of Fluoride concentration in water.

\section{RESULT AND DISCUSSION}

Fluoride is a widely distributed element in all type of rocks in one or the other form. Its affinity towards sodium is high. Hence, its concentration is high in ground waters, where the temperature is high and rainfall is less. Soil porosity and permeability also has a key role in building up the Fluoride concentrations. High concentration can make water unpalatable and, therefore, unfit for drinking or livestock watering. High concentration can occur near sewage, irrigation drains, and waste outlets.

Fluoride has little significance in industrial waters, but in amount of 1 to $1.5 \mathrm{ppm}$ in drinking water is an effective preventive of dental curies. Above this amount, fluoride may cause dental and skeletal fluorosis. Such water should be defluoridated to reduce the fluoride concentration in water to the acceptable levels. In the present work Fluoride ion concentration varied from 0.10 to 0.60 ppm. The values obtained are well below permissible limit, 1 ppm, prescribed by ICMR3.

Table 1: Fluoride Concentration of Ground Water In Osmanabad District

\begin{tabular}{lllllllllllll}
\hline Entry & June & July & Aug & Sept & Oct. & Nov. & Dec. & Jan. & Feb. & Mar. & April & May \\
\hline 1 & 0.1 & 0.4 & 0.2 & 0.0 & 0.1 & 0.2 & 0.1 & 0.0 & 0.2 & 0.1 & 0.1 & 0.0 \\
2 & 0.6 & 0.6 & 0.0 & 0.2 & 0.4 & 0.1 & 0.3 & 0.3 & 0.2 & 0.1 & 0.2 & 0.2 \\
3 & 0.1 & 0.1 & 0.1 & 0.3 & 0.2 & 0.1 & 0.1 & 0.4 & 0.3 & 0.2 & 0.2 & 0.1 \\
4 & 0.4 & 0.2 & 0.2 & 0.4 & 0.1 & 0.0 & 0.6 & 0.4 & 0.3 & 0.1 & 0.2 & 0.3 \\
5 & 0.0 & 0.3 & 0.6 & 0.2 & 0.1 & 0.0 & 0.4 & 0.3 & 0.2 & 0.1 & 0.3 & 0.2 \\
6 & 0.0 & 0.2 & 0.1 & 0.1 & 0.3 & 0.1 & 0.2 & 0.1 & 0.2 & 0.2 & 0.2 & 0.2 \\
7 & 0.1 & 0.3 & 0.0 & 0.3 & 0.6 & 0.3 & 0.6 & 0.1 & 0.3 & 0.2 & 0.1 & 0.3 \\
8 & 0.3 & 0.5 & 0.0 & 0.1 & 0.1 & 0.3 & 0.3 & 0.4 & 0.2 & 0.3 & 0.1 & 0.3 \\
9 & 0.3 & 0.2 & 0.2 & 0.0 & 0.2 & 0.2 & 0.3 & 0.2 & 0.3 & 0.2 & 0.0 & 0.4 \\
10 & 0.1 & 0.0 & 0.1 & 0.1 & 0.2 & 0.2 & 0.0 & 0.2 & 0.2 & 0.2 & 0.3 & 0.1 \\
11 & 0.2 & 0.3 & 0.1 & 0.2 & 0.5 & 0.1 & 0.2 & 0.1 & 0.4 & 0.1 & 0.2 & 0.5 \\
12 & 0.3 & 0.3 & 0.3 & 0.4 & 0.2 & 0.1 & 0.1 & 0.3 & 0.2 & 0.2 & 0.0 & 0.4 \\
13 & 0.2 & 0.2 & 0.3 & 0.3 & 0.1 & 0.2 & 0.6 & 0.2 & 0.3 & 0.2 & 0.3 & 0.5 \\
14 & 0.5 & 0.0 & 0.0 & 0.5 & 0.2 & 0.4 & 0.0 & 0.4 & 0.2 & 0.3 & 0.0 & 0.2 \\
15 & 0.4 & 0.1 & 0.2 & 0.2 & 0.0 & 0.3 & 0.1 & 0.3 & 0.1 & 0.1 & 0.4 & 0.0 \\
16 & 0.4 & 0.1 & 0.1 & 0.2 & 0.0 & 0.4 & 0.2 & 0.2 & 0.2 & 0.1 & 0.0 & 0.4 \\
17 & 0.1 & 0.2 & 0.0 & 0.4 & 0.6 & 0.3 & 0.2 & 0.3 & 0.5 & 0.3 & 0.1 & 0.2 \\
18 & 0.3 & 0.0 & 0.3 & 0.1 & 0.3 & 0.4 & 0.1 & 0.2 & 0.2 & 0.2 & 0.3 & 0.4 \\
19 & 0.2 & 0.4 & 0.2 & 0.2 & 0.2 & 0.2 & 0.2 & 0.4 & 0.1 & 0.3 & 0.4 & 0.5 \\
20 & 0.2 & 0.4 & 0.1 & 0.3 & 0.1 & 0.1 & 0.2 & 0.3 & 0.2 & 0.1 & 0.2 & 0.3 \\
\hline
\end{tabular}




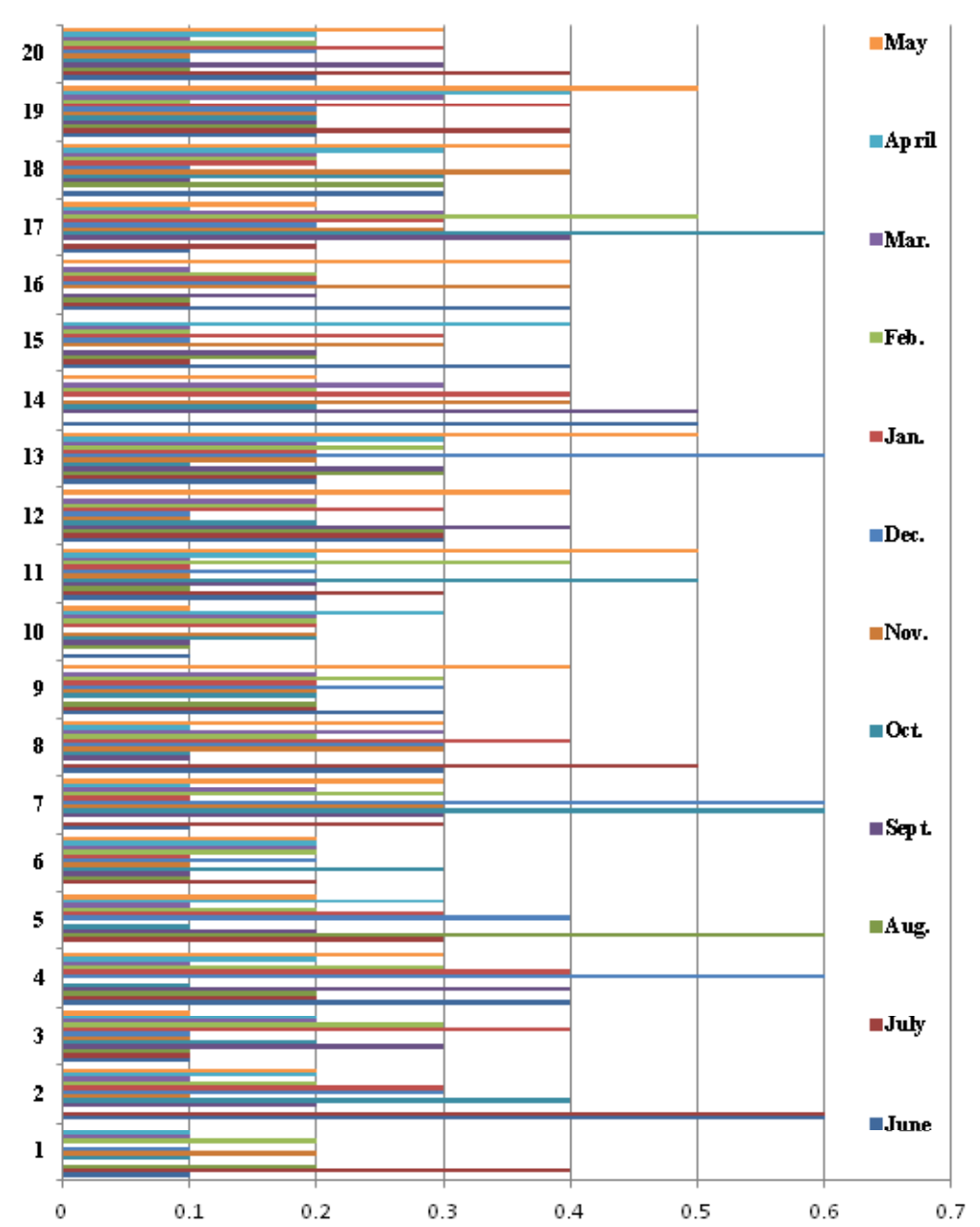

Fig. 1: Variations in Fluoride concentration of Ground Water in Osmanabad District

The results of fluoride concentration shows in form of table and figure like Omerga (Table 1, Entry 1-5), Lohara (Table 1, Entry 6-10), Tuljapur (Table 1, Entry 11-15), and Osmanabad (Table 1, Entry 16-20) tehsils respectively.Variations in Fluoride concentration of Ground Water are shown in figure 1 . Above tables shows monthly variation in concentration of fluoride but the fluoride content in water is low due to this no dental and Skelton problem arises in the study area.
From the information deduced from this study, it was found that sample around industrial area having slightly larger rang of fluoride concentration but some water samples having other impurities were not fit for drinking without proper treatment.

\section{ACKNOWLEDGEMENTS}

We are thankful to principal, Dr. N.D.Shinde, Shri ChhatrapatiShivaji College, Omerga for providing necessary laboratory facilities. 


\section{REFERENCE}

1. Apambire W.M.,Boyle D.R. and Michel F.A., Environmental Geology, 35(1), 13-24 (1997).

2. $\quad \mathrm{NRC}($ National Research Council),Drinking water and public Health, Vol.No.1,Safe drinking water committee, National Academy Press, Washington D.C.(1997)

3. Singh, Naveen Kumar,Kadam D.S., Ultra Chemistry, 2(2), 227-228(2006).

4. American Public Health Association, American Water works Association. Standard Methods for the Examination of water and wastewater. Washington, D.C, USA: Water Environment Federation, 20th Edition (2001)

5. Abyaneh et al., Testing procedures (2005).

6. Bannerman R. T., Owens D. W., Dodds R. B., Hornewer N.J., Water Science and technology, 28(3-5), 241-259 (1993).

7. Drinking water inspectorate, Ergon house, Horse ferry London, 3rd edition (2007).

8. Goonetilleke A., Thomas E., Ginn S., Gilbert D. Journal of Environmental Management,
74, 31-42 (2005).

9. Sharma M. R., Gupta A. B., Prevention and control of pollution in streams of outer Himalayas, 35(2004).

10. Singh, Naveen Kumar,Kadam D.S., Current World Environment, 2(1), 97-98(2007).

11. Singh, Naveen Kumar,Kadam D.S., Int. J. Chem.Sc. 5(2), 592-596(2007).

12. Standard method for the Examination of water and waste water $18^{\text {th }}$ edition prepared and published jointly by APHA, AWWA, and WEF (1992).

13. World Health Organization (WHO), International Standard for Drinking water Geneva (1984)

14. American Society for Testing and Materials, Annual Book of ASTM Standard, Part-23, ASTM-Philadelphia(1972)

15. A.I.Vogel text Book of Qualitative inorganic analysis, 2nd edition, Longman and Green Co.,London,191 (1985) 